93 RD ANNUAL MEETING AND EXHIBITION HOTEL RESERVATION INSTRUCTIONS

\section{HAVE THE}

FOLLOWING READY WHEN CALLING

TO MAKE

\section{RESERVATIONS:}

1. Membership status

2. Name of Convention

3. 1st, 2nd and 3rd choice hotel

4. Arrival and departure dates

5. Type of room single, double ( 2 people, 1 bed), twin ( 2 people, 2 beds)

6. Names of ALL occupants of $\operatorname{room}(\mathrm{s})$

7. Address or fax number to which confirmation should be sent

8. Gredit card name, number, and expiration date (for credit card deposit)

\section{NO FORM NEEDED ... CALL IN YOUR \\ RESERVATION TO THE WASHINGTON CONVENTION \& VISITORS ASSOCIATION (WCVA)! \\ 1-800-535-3336 • US \& Canada}

(202) 842-2930 • Metro Washington Area \& International (202) 289-8079 • Fax (International Attendees Only)

\section{DEADLINE FOR RESERVATIONS: AUGUST 4, 1997}

Note: If you have any disabilities that require special facilities in your sleeping room, please let the agent know at the time you make your reservation.

\section{DEPOSIT}

A $\$ 100.00$ per room deposit is required for all reservations. The deposit amount is payable by credit card or check.

Credit Card Deposit: Your credit card will be charged $\$ 100.00$ after

May 1, 1997. Most credit cards are accepted. Your credit card statement will read "Convention Housing Deposit, Washington, D.C."

Check Deposit: An invoice for the $\$ 100.00$ per room deposit will be mailed to you. Payment must be received within 15 days of the invoice date or your reservation will be cancelled. Do not send payment without the invoice stub.

\section{CONFIRMATIONS}

Your room confirmation will be sent upon acceptance of your credit card charge or check. For groups requesting six (6) rooms or more, only one credit card will be accepted for the deposit. All returned checks are subject to a $\$ 25.00$ service charge.

\section{CHANGES}

On or before August 4, 1997 all changes should be made directly with the WCVA housing service. After this date all changes should be made directly with the hotel.

\section{CANCELLATIONS}

Cancellations made on or before August 4, 1997 should be made with the WCVA housing service and will be refunded in full. The WCVA housing service will issue the refund.

Cancellations made after August 4, 1997 and prior to 72 hours of arrival should be made with the hotel. A $\$ 10.00$ fee will be deducted from your deposit. The hotel will issue the refund. Your reservation must be cancelled 72 hours prior to arrival or the entire $\$ 100.00$ deposit is forfeited.

\section{RATES}

You must be an APSA member to obtain discounted room rates at the participating hotels. To become a member, call APSA at (202) 483-2512 or visit our web site: http://www.apsanet.org 


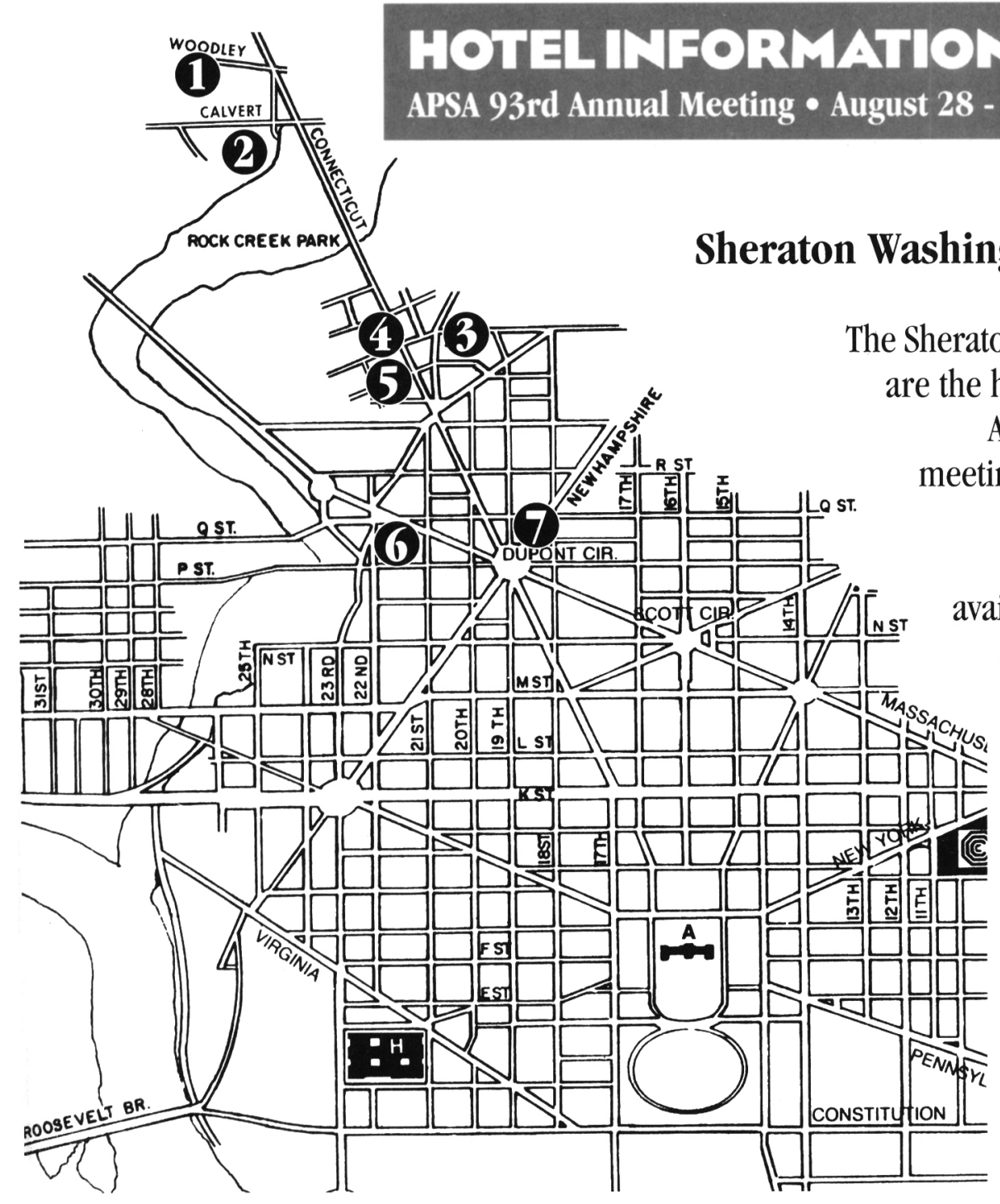

1) Sheraton Washington 2660 Woodley Road, NW Member Rates: $\$ 89$ Single/\$119 Double Nonmember Rates: \$220 Single/\$220 Double

Headquarters hotel and largest convention and business luxury hotel in the nation's capital; restaurants, pastry shop, barber shop, valet parking; near Woodley Park-Zoo metro stop

2

Omni Shoreham

2500 Calvert Street, NW

Member Rates:

\$89 Single/\$119 Double

Nonmember Rates:

\$175 Single/\$205 Double

Headquarters hotel ideally located near the Woodley Park-Zoo metro stop; luxury property adjacent to Rock Creek Park; tennis courts, fitness center.
Washington Hilton and Towers

1919 Connecticut Avenue, NW

Member Rates:

$\$ 89$ Single/\$119 Double

Nonmember Rates:

\$230 Single/\$250 Double

Resort-like hotel located near trendy multicultural restaurants in Adams Morgan; serving American, Italian, Vietnamese, Ethiopian cuisines.

4

Hotel Sofitel Washington

1914 Connecticut Avenue, NW

Member Rates:

\$89 Single/Double

Nonmember Rates:

\$195 Single/\$215 Double

Elegant hotel in the heart of Embassy Row; across from Washington Hilton; located 3 blocks from Dupont Circle metro stop; health club, turndown.
F Washington Courtyard by

Marriott

1900 Connecticut Avenue, NW

Member Rates:

\$89 Single/\$99 Double

Nonmember Rates:

\$135 Single/\$145 Double

Premier hotel in the Embassy Row area; across from Washington Hilton; charming rooms, underground parking.

Radisson Barcelo Hotel

2121 P Street, NW

Member Rates:

\$89 Single/Double

Nonmember Rates:

\$149 Single/Double

Eccentric hotel located in the fashionable West End neighborhood near Dupont

Circle metro stop; gallery artwork, rooftop sun deck, outdoor pool.

Dupont Plaza Hotel

1500 New Hampshire Avenue, NW

Member Rates:

$\$ 89$ Single/Double

Nonmember Rates:

\$130 Single/\$150 Double

Luxury hotel close to fine restaurants, exclusive shops, sidewalk cafes, Dupont Circle metro stop; sightseeing tour pickup. 